\title{
Analysis of Factors Affecting China's OFDI
}

\author{
Xuezhong Chen and Jialin Lin \\ Bussiness School, The University of Jinan, China
}

\begin{abstract}
The OFDI in China increased from 2.6 billion U.S. dollars in 1997 to 196.1 billion U.S. dollars in 2016, showing that the OFDI in China has achieved a rapid development. With the implementation of the trade policy"Belt and Road", and the increasing influence of uncertainties in foreign trade, it is of great significance to study the factors affecting OFDI in China. In this paper, it selected 15 related indicators from 1997 to 2016 and used the principal component analysis to analysis the factors affecting OFDI in China, and then drew the conclusions: the main factors affecting OFDI in China rank from the greatest influence to the least influence are the basic economic factors, financial support factors and world economic factors. Meanwhile, it proposes the measures like strengthening the foreign trade, improving the economic strength, as well as strengthening the output of technology and capital in China.
\end{abstract}

Keywords-OFDI; influencing factors; principal component analysis

\section{INTRODUCTION}

In the work meeting of the Ministry of Commerce in December 2017, Shan ZHONG pointed out that China should continue to support foreign investment in enterprises with clear strategies and adherence to their main business. On the one hand, we should guide enterprises to become bigger and stronger, focus on global allocation of resources, and enhance international competitiveness; on the other hand, we need to adapt to the development of China's domestic economy, promote the transformation of made in china into created in China, and drive Chinese equipment, Chinese standards, Chinese technology and services to "go out". At abroad, Khanindra Ch.Das used simultaneous equation model and panel data to analyze the data from 1996 to 2010, and he found that the economic development level, r\&d cost and the degree of globalization had significant influence on OFDI[1]. Other scholars believe that the attractiveness of domestic market attractiveness (Chetty S and Campbellhunt C,2004), domestic technical level (Andersson S et al.2010), high innovation ability and learning ability (Covin and Miller,2014) are important factors for enterprises to rapidly enter host countries for OFDI[2][3][4]. At home, Zhanqi YAO used OLS, system GMM and other models to study the factors affecting China's OFDI in the countries along the "Belt and Road" from 2003 to 2014. The research shows that the improvement of economic level is the main reason for China's OFDI[5]. Licheng QIU and Ramasam B used OLS regression analysis to show that resource demand and labor costs - wages and OFDI change in a positive direction, while exports and China's OFDI have a negative direction[6][7]. Weifu ZHANG used the method of multiple regression OLS to get the conclusion that economic scale and government support had positive effect on China's OFDI[8]. Based on 15 related factors, this paper selects the data from 1997 to 2016 for principal component analysis, and finally draws conclusions and proposes some measures to promote China's OFDI.

\section{FACTORS AFFECTING CHINA'S OFDI}

\section{A. Index Selection and Data Description}

This paper uses principal component analysis to analyze the influencing factors of China's OFDI, in this paper, the explained variables select the OFDI flow (Y), the explaining variables contain six first-level indicators, and the 15 secondary indicators that reflect the factors affecting China's OFDI are selected as the original variables, the six primary indicators are China's macroeconomic development, fiscal policy, foreign economic and trade, monetary policy, industrial policy and world macroeconomic operation. Among them, macroeconomic development includes GDP(x1), CPI(x2) and the number of top 500 Chinese enterprises(x3). Fiscal policy includes the growth rate of fiscal revenue(x4) and the growth rate of fiscal expenditure(x5). Foreign economic trade include foreign exchange reserves(x6), RMB to us dollar exchange rate(x7), total import and export trade(x8), and the volume of absorbing FDI(x9). The monetary policy includes the issuance of monetary reserve by monetary authority(x10) and sources of RMB credit funds for financial institutions(x11); Industrial policies include the average wage of urban employees(x12) and the number of overseas quoted companies(x13); World macroeconomic operation includes global economic growth rate(x14) and the growth rate of foreign investment in the world(x15). The data of these variables are derived from the "National Bureau of Statistics of China", "Department of Outward Investment and Economic Cooperation of the Ministry of Commerce of the People's Republic of China", and "Fortune Chinese Network". We used Spss23.0 software and select 1997-2016 years' data to make an empirical analysis of the 15 secondary indicators.

\section{B. An Empirical Analysis of the Factors Influencing China's OFDI}

\section{1) Data Normalization Processing}

As the measurement units of different indexes are different, the numerical problems caused by original data are directly adopted, and formula (1) is used for standardized processing to transform original data into dimensionless indexes. On this basis, principal component analysis is carried out.

$$
Z_{\mathrm{ij}} \equiv \frac{X_{\mathrm{ij}}-\overline{X_{j}}}{\sigma_{j}}
$$

Among them, $z_{i j}$ represents the normalized value of the $j$ 
column of the ith row; $x_{i j}$ represents the original value of the $\mathrm{j}$ column of the ith row; $\bar{x}_{j}$ represents the average value of column $\mathrm{j} ; \quad \sigma_{j}$ represents the standard deviation of column $\mathrm{j}$.

2) Correlation Coefficient and Multicollinearity Test
Before principal component analysis, We need to test the necessity and feasibility of principal component analysis. There are two kinds of test methods: correlation coefficient analysis and KMO test. The test results are shown in table 1 and table 2 .

TABLE I. ANALYSIS RESULTS OF CORRELATION COEFFICIENT

\begin{tabular}{|c|c|c|c|c|c|c|c|c|c|c|c|c|c|c|c|}
\hline variable & $\mathrm{x} 1$ & $\mathrm{x} 2$ & $\mathrm{x} 3$ & $\mathrm{x} 4$ & $\mathrm{x} 5$ & $\mathrm{x} 6$ & $\mathrm{x} 7$ & $\mathrm{x} 8$ & $\mathrm{x} 9$ & $\mathrm{x} 10$ & $\mathrm{x} 11$ & $\mathrm{x} 12$ & $\mathrm{x} 13$ & $\mathrm{x} 14$ & $\mathrm{x} 15$ \\
\hline $\mathrm{x} 1$ & 1.000 & .995 & .994 & -.525 & -.530 & .954 & -.942 & .965 & .976 & .996 & .993 & .999 & .947 & -.167 & -.197 \\
\hline $\mathrm{x} 2$ & .995 & 1.000 & .985 & -.495 & -.479 & .968 & -.962 & .973 & .984 & .992 & .980 & .990 & .942 & -.173 & -.201 \\
\hline $\mathrm{x} 3$ & .994 & .985 & 1.000 & -.563 & -.572 & .942 & -.929 & .950 & .959 & .988 & .990 & .992 & .919 & -.158 & -.196 \\
\hline $\mathrm{x} 4$ & -.525 & -.495 & -.563 & 1.000 & .704 & -.388 & .419 & -.358 & -.409 & -.486 & -.580 & -.531 & -.359 & .433 & .319 \\
\hline $\mathrm{x} 5$ & -.530 & -.479 & -.572 & .704 & 1.000 & -.377 & .320 & -.402 & -.408 & -.501 & -.580 & -.538 & -.408 & -.022 & .044 \\
\hline $\mathrm{x} 6$ & .954 & .968 & .942 & -.388 & -.377 & 1.000 & -.989 & .987 & .980 & .968 & .916 & .944 & .917 & -.182 & -.222 \\
\hline $\mathrm{x} 7$ & -.942 & -.962 & -.929 & .419 & .320 & -.989 & 1.000 & -.969 & -.973 & -.952 & -.904 & -.931 & -.988 & .252 & .278 \\
\hline $\mathrm{x} 8$ & .965 & .973 & .950 & -.358 & -.402 & .987 & -.969 & 1.000 & .983 & .978 & .927 & .958 & .946 & -.113 & -.196 \\
\hline $\mathrm{x} 9$ & .976 & .984 & .959 & -.409 & -.408 & .980 & -.973 & .983 & 1.000 & .983 & .952 & .972 & .951 & -.182 & -.216 \\
\hline $\mathrm{x} 10$ & .996 & .992 & .988 & -.486 & -.501 & .968 & -.952 & .978 & .983 & 1.000 & .982 & .995 & .956 & -.163 & -.202 \\
\hline $\mathrm{x} 11$ & .993 & .980 & .990 & -.580 & -.580 & .916 & -.904 & .927 & .952 & .982 & 1.000 & .995 & .933 & -.178 & -.183 \\
\hline $\mathrm{x} 12$ & .999 & .990 & .992 & -.531 & -.538 & .944 & -.931 & .958 & .972 & .995 & .995 & 1.000 & .955 & -.178 & -.198 \\
\hline $\mathrm{x} 13$ & .947 & .942 & .919 & -.359 & -.408 & .917 & -.888 & .946 & .951 & .956 & .933 & .955 & 1.000 & -.150 & -.131 \\
\hline $\mathrm{x} 14$ & -.167 & -.173 & -.158 & .433 & -.022 & -.182 & .252 & -.113 & -.182 & -.163 & -.178 & -.178 & -.150 & 1.000 & .659 \\
\hline $\mathrm{x} 15$ & -.197 & -.201 & -.196 & .319 & .044 & -.222 & .278 & -.196 & -.216 & -.202 & -.183 & -.198 & -.131 & .659 & 1.000 \\
\hline
\end{tabular}

TABLE II. KMO AND BARTLETT TEST

\begin{tabular}{|c|c|c|}
\hline \multicolumn{3}{|l|}{ KMO and Bartlett's Test } \\
\hline \multicolumn{2}{|c|}{ Kaiser-Meyer-Olkin Measure of Sampling Adequacy. } & .749 \\
\hline \multirow{3}{*}{ Bartlett's Test of Sphericity } & Approx. Chi-Square & 792.280 \\
\hline & $\mathrm{df}$ & 105 \\
\hline & Sig. & .000 \\
\hline
\end{tabular}

According to the results in table 1 and table 2, on the one hand, it can be seen from the results of correlation coefficient analysis, there is a strong correlation between some variables, and the highest one can reach 0.999 , it indicates that there is a correlation between the 15 indicators, so it has the premise of principal component analysis. On the other hand, the KMO test is an index for comparing the simple correlation coefficient and the partial correlation coefficient between variables. The closer the value of the KMO test is to 1 , indicating that the correlation between the variables is stronger, which makes it more suitable for principal component analysis. Caesar gives a test standard, and the value of the KMO test above 0.5 are suitable for principal component analysis[9]. As can be seen from Table 2, the test result is 0.749 , so the sample data of this paper can be analyzed by principal component analysis.

\section{3) Principal Component Analysis}

a) Analysis of Variance Contribution Rate and Extraction of Common Factors

The extraction of the common factor must have two criteria at the same time. The first criterion is that the eigenvalue corresponding to the common factor must be greater than one; the second criterion is that the cumulative variance contribution rate of the common factor must be greater than $80 \%$. According to these two criteria, it can be seen from Table 3 that the eigenvalues of variable 1, variable 2 and variable 3 are all greater than 1 and the cumulative variance contribution of these three common factors is $94.842 \%$, they meet the requirements of common factor extraction. Therefore, three common factors will be extracted in this paper. 
TABLE III. TOTAL VARIANCE INTERPRETATION AND PRINCIPAL COMPONENT EXTRACTION ANALYSIS RESULTS

\begin{tabular}{|c|c|c|c|c|c|c|c|c|c|}
\hline \multicolumn{10}{|c|}{ Total Variance Explained } \\
\hline \multirow{2}{*}{ Component } & \multicolumn{3}{|c|}{ Initial Eigenvalues } & \multicolumn{3}{|c|}{\begin{tabular}{|llll}
$\begin{array}{l}\text { Extraction } \\
\text { Loadings }\end{array}$ & Sums of & Squared \\
\end{tabular}} & \multicolumn{3}{|c|}{ Rotation Sums of Squared Loadings } \\
\hline & Total & $\begin{array}{l}\% \\
\text { Variance }\end{array}$ & $\begin{array}{l}\text { Cumulative } \\
\%\end{array}$ & Total & $\begin{array}{l}\% \\
\text { Variance }\end{array}$ & $\begin{array}{l}\text { Cumulative } \\
\%\end{array}$ & Total & $\begin{array}{l}\% \\
\text { Variance }\end{array}$ & Cumulative \% \\
\hline 1 & 11.235 & 74.899 & 74.899 & 11.235 & 74.899 & 74.899 & 10.175 & 67.833 & 67.833 \\
\hline 2 & 1.737 & 11.582 & 86.481 & 1.737 & 11.582 & 86.481 & 2.179 & 14.530 & 82.363 \\
\hline 3 & 1.254 & 8.361 & 94.842 & 1.254 & 8.361 & 94.842 & 1.872 & 12.479 & 94.842 \\
\hline 4 & 388 & 2.588 & 97.429 & & & & & & \\
\hline 5 & .187 & 1.249 & 98.678 & & & & & & \\
\hline 6 & .115 & .769 & 99.447 & & & & & & \\
\hline 7 & .049 & 326 & 99.773 & & & & & & \\
\hline 8 & .016 & .109 & 99.882 & & & & & & \\
\hline 9 & .007 & .045 & 99.927 & & & & & & \\
\hline 10 & .005 & .035 & 99.962 & & & & & & \\
\hline 11 & .003 & .020 & 99.982 & & & & & & \\
\hline 12 & .002 & .016 & 99.998 & & & & & & \\
\hline 13 & .000 & .002 & 100.000 & & & & & & \\
\hline 14 & $5.185 \mathrm{E}-5$ & .000 & 100.000 & & & & & & \\
\hline 15 & $1.344 \mathrm{E}-5$ & $8.962 \mathrm{E}-5$ & 100.000 & & & & & & \\
\hline
\end{tabular}

\section{b) Factor Loading Matrix after Rotation}

Due to the fact that the actual meaning of the unrotated common factor is not easy to be explained, the orthogonal rotation through maximizing the variance of the common factor can make each variable highly correlated to only one common factor, so the related problems can be explained more easily. It can be seen from table 4 that in the rotated factor loading matrix, each common factor only has a large load with several original indexes, we name it according to the load factor and then the model of each economic index is obtained:

$$
\begin{aligned}
& x_{1}=0.948 F_{1}+0.300 F_{2}-0.081 F_{3} \\
& x_{2}=0.961 F_{1}+0.246 F_{2}-0.092 F_{3} \\
& x_{3}=0.925 F_{1}+0.355 F_{2}-0.075 F_{3} \\
& x_{15}=-0.120 F_{1}-0.037 F_{2}+0.882 F_{3}
\end{aligned}
$$

TABLE IV. ROTATED COMPONENT MATRIX ANALYSIS RESULTS

\begin{tabular}{|c|c|c|c|c|c|c|}
\hline \multirow{2}{*}{ variable } & \multicolumn{2}{|c|}{ Component Matrix } & \multicolumn{3}{c|}{ Rotated Component Matrix } \\
\cline { 2 - 7 } & $\mathrm{F} 1$ & $\mathrm{~F} 2$ & $\mathrm{~F} 3$ & $\mathrm{~F} 1$ & $\mathrm{~F} 2$ & $\mathrm{~F} 3$ \\
\hline $\mathrm{x} 1$ & .996 & .054 & -.017 & .948 & .300 & -.081 \\
\hline $\mathrm{x} 2$ & .993 & .060 & .040 & .961 & .246 & -.092 \\
\hline $\mathrm{x} 3$ & .990 & .041 & -.075 & .925 & .355 & -.075 \\
\hline $\mathrm{x} 4$ & -.543 & .502 & .597 & -.256 & -.840 & .365 \\
\hline $\mathrm{x} 5$ & -.529 & .064 & .790 & -.290 & -.901 & -.109 \\
\hline $\mathrm{x} 6$ & .966 & .074 & .177 & .972 & .107 & -.117 \\
\hline $\mathrm{x} 7$ & -.956 & .001 & -.218 & -.956 & -.086 & .199 \\
\hline $\mathrm{x} 8$ & .970 & .133 & .155 & .983 & .114 & -.056 \\
\hline $\mathrm{x} 9$ & .981 & .075 & .142 & .978 & .144 & -.107 \\
\hline $\mathrm{x} 10$ & .995 & .068 & .028 & .962 & .255 & -.081 \\
\hline $\mathrm{x} 11$ & .985 & .029 & -.098 & .912 & .377 & -.078 \\
\hline
\end{tabular}

TABLE IV CONTINUE

\begin{tabular}{|c|c|c|c|c|c|c|}
\hline $\mathrm{x} 12$ & .994 & .045 & -.027 & .942 & .311 & -.086 \\
\hline $\mathrm{x} 13$ & .945 & .137 & .114 & .950 & .143 & -.036 \\
\hline $\mathrm{x} 14$ & -.219 & .869 & -.219 & -.072 & -.085 & .915 \\
\hline $\mathrm{x} 15$ & -.246 & .815 & -.265 & -.120 & -.037 & .882 \\
\hline
\end{tabular}

It can be seen from the model and Table 4 that the factor load of the common factor F1 is mainly distributed in indicators such as $\mathrm{x} 1, \mathrm{x} 2, \mathrm{x} 3, \mathrm{x} 6, \mathrm{x} 7, \mathrm{x} 8, \mathrm{x} 9, \mathrm{x} 10, \mathrm{x} 11, \mathrm{x} 12$, $\mathrm{x} 13$, and the load of these indicators exceeds 0.8 . Moreover, the impact of these factors on China's OFDI is mainly reflected in the domestic and international economic aspects, so the public factor F1 is named as the "basic economy" factor. The public factor F2 is mainly distributed in indicators such as $\mathrm{x} 4$ and $\mathrm{x} 5$. The impact of these factors on China's OFDI is mainly reflected in financial support aspects. Therefore, the public factor F2 is named as "financial support" factor. X14 and $\mathrm{x} 15$ are highly correlated, and the common factor F3 is named the "world economy" factor.So far, this study reduced 15 factors influencing China's OFDI to "basic economic factor", "financial support factor" and "world economic factor" through principal component analysis, and then examined the influencing factors of China's OFDI.

\section{c) The Analysis of Factor Loading Matrix}

The mathematical model is established on the basis of three principal components: 


$$
\begin{aligned}
& F 1=0.948 z_{1}+0.961 z_{2}+0.925 z_{3}-0.256 z_{4}-0.290 z_{5}+0.972 z_{6} \\
& -0.956 z_{7}+0.983 z_{8}+0.978 z_{9}+0.962 z_{10}+0.985 z_{11}+0.942 z_{12} \\
& +0.950 z_{13}-0.072 z_{14}-0.120 z_{15} \\
& F 2=0.300 z_{1}+0.246 z_{2}+0.355 z_{3}-0.840 z_{4}-0.901 z_{5}+0.107 z_{6} \\
& -0.086 z_{7}+0.114 z_{8}+0.144 z_{9}+0.255 z_{10}+0.377 z_{11}+0.311 z_{12} \\
& +0.143 z_{13}-0.085 z_{14}-0.037 z_{15} \\
& F 3=-0.081 z_{1}-0.092 z_{2}-0.075 z_{3}-0.365 z_{4}-0.109 z_{5}-0.117 z_{6} \\
& +0.199 z_{7}-0.056 z_{8}-0.107 z_{9}-0.081 z_{10}-0.078 z_{11}-0.086 z_{12} \\
& -0.036 z_{13}+0.915 z_{14}+0.882 z_{15}
\end{aligned}
$$

The data after standardization is brought into formula (3), and the three principal component scores affecting China's OFDI are obtained, as shown in Table 5.

TABLE V. COMPONENT SCORE

\begin{tabular}{|l|l|l|l|}
\hline Year & F1 & F2 & F3 \\
\hline 1997 & -11.60897 & -2.54063 & 1.82913 \\
\hline 1998 & -11.35308 & -2.20752 & 1.88568 \\
\hline 1999 & -11.68731 & -3.35557 & 2.44402 \\
\hline 2000 & -11.07972 & -3.10782 & 1.70263 \\
\hline 2001 & -10.14857 & -3.1408 & -1.79842 \\
\hline 2002 & -9.10022 & -1.7778 & -0.26226 \\
\hline 2003 & -8.02218 & -0.72818 & 0.87324 \\
\hline 2004 & -7.37011 & -2.07913 & 2.77625 \\
\hline 2005 & -6.07162 & -2.13348 & 0.36608 \\
\hline 2006 & -4.6712 & -2.21097 & 2.37858 \\
\hline 2007 & -2.62891 & -3.63498 & 1.35877 \\
\hline 2008 & 1.28246 & -1.64694 & -2.13521 \\
\hline 2009 & 3.12642 & 0.56638 & -4.46138 \\
\hline 2010 & 5.47288 & 0.32819 & 0.58012 \\
\hline 2011 & 8.50852 & 0.02052 & -1.18153 \\
\hline 2012 & 11.01673 & 3.12962 & -1.62535 \\
\hline 2013 & 13.9346 & 4.85813 & -1.34253 \\
\hline 2014 & 15.78887 & 6.01112 & -1.13341 \\
\hline 2015 & 16.71853 & 5.90478 & -0.93642 \\
\hline 2016 & 17.92352 & 7.73636 & -1.15125 \\
\hline
\end{tabular}

It can be seen from the analysis results that, in the basic economic factors (F1), each indicator has a positive promoting effect on China's OFDI, it becomes the first major factor. In the financial support factor (F2), the growth rate of fiscal revenue and the growth rate of fiscal expenditure have a significant impact on China's OFDI, indicating that national financial support has a promoting effect on China's overseas investment. In the world economic factor (F3), the influence coefficient of global economic growth rate and the growth rate of foreign investment in the world all reached above 0.8, indicating that the improvement of overseas investment environment and the improvement of world economic trade have promoted China's OFDI. By analyzing the scores of the three principal components between 1997 and 2016, it can be seen that the three principal components have an obvious influence on China's OFDI, indicating that the principal component analysis is reasonable.

\section{CONCLUSIONS AND POLICY RECOMMENDATIONS}

The basic economic factors make the greatest contribution to China's OFDI, indicating that keeping a good development of domestic economic as well as an economic growth rate which is stable and consist with China's national conditions is an important basis for promoting the increase of China's OFDI. The financial support factor is an important force that reflects the source of funds for China's OFDI and promotes the sustained, rapid and healthy development of a country's economy. Therefore, adequate financial funds to support China's OFDI are an important guarantee for it. And the world economic factor reflects the economic development condition of the main capital exporting nations in the world. In the process of the world's economic development, international trades and investments become the engine of overseas investments. Having a stable economic investment environment not only has unique advantages for China's OFDI, but also is benefit to achieve win-win and cooperation.

Based on the above research conclusions, this paper proposes several policy suggestions:(1). Promote steady economic growth and keep a good condition of domestic economic development. (2). Carry out a strategy combining trade and investment and attach great importance to the expansion of overseas markets. (3). Increase the output of capital and technology of China and so on. (4). Implement multi-regional development strategies and strengthen the construction of overseas economic and trade cooperation. (5). Play the functions of government effectively and establish a stable and effective investment market.

\section{ACKNOWLEDGMENT}

Project "Evolutions of Decision-Making Governance and Growth Path of China Multinational Corporations Based on Computational Experiment" Supported by the National Natural Science Foundation of China. (Grant No. 71371085)

\section{REFERENCES}

[1] J. Das K C, Home Country Determinants of Outward FDI from Developing Countries, vol. 7, no.1, Margin the Journal of Applied Economic Research,2013, pp.93-116.

[2] J. Chetty S. Campbellhunt C, A Strategic Approach to Internationalization: A Traditional Versus a "Born-Global" Approach, vol. 12, no. 1, Journal of International Marketing, 2004, pp.57-81.

[3] J. Andersson S. Gabrielsson J. Wictor I, International Activities in Small Firms: Examining Factors Influencing the Internationalization and Export Growth of Small Firms, vol. 21, no.1, Canadian Journal of Administrative Sciences, 2010, pp.22-34.

[4] J. Jeffrey G. Covin Samuel and Pauline Glaubinger Professor of Entrepreneurship, Miller D, International Entrepreneurial Orientation: Conceptual Considerations, Research Themes, vol. 38, no. 1, Measurement Issues, and Future Research Directions. Entrepreneurship Theory \& Practice, 2014, pp.11-44.

[5] J. Zhanqi YAO, Influencing Factors and Location Choice of China's Foreign Direct Investment Efficiency under the "Belt and Road" Strategy, no. 12, Economic Aspects, 2016, pp.59-66.(in chinese)

[6] J. Licheng QIU. Fengli WANG, An Empirical Study on the Main Macro Influencing Factors of China's Foreign Direct Investment, No. 06, International Trade Issues, 2008, pp.78-82.(in chinese)

[7] J. Ramasamy B. Yeung M. Laforet S, China's outward foreign direct investment: Location choice and firm ownership.vol. 47, no. 1, Journal 
of World Business, 2012, pp.17-25.

[8] J. Weifu ZHANG, Research on Factors Affecting Foreign Direct Investment of Chinese Enterprises, no. 11, China Industrial Economy, 2008,pp.130-140.(in chinese)

[9] J. Zhibing CAI. Qiang ZU, Research on the Influencing Factors of China's Foreign Direct Investment Growth — Based on Factor Analysis Model, no. 03, International Business (Journal of University of International Business and Economics), 2012, pp.80-88.(in Chinese) 